Original Paper

\title{
Meningkatkan Aktivitas dan Hasil Belajar Siswa dengan Penerapan Pembelajaran Kooperatif Numbered Heads Together (NHT)
}

\author{
Moh Taoefik ${ }^{1^{*}}$ \\ ${ }^{1}$ Sekolah Menengah Atas Negeri 2 Narmada, Indonesia
}

*Corresponding Author:

Moh Taoefik, Sekolah

Menengah Atas Negeri 2

Narmada, Indonesia.

Email:

moh_taoefik@yahoo.com

\begin{abstract}
Abstrak: Penelitian Tindakan Kelas ini bertujuan untuk mengetahui apakah pembelajaran tipe NHT ini dapat meningkatkan aktifitas dan hasil belajar siswa, selain itu juga melatih siswa untuk saling bekerja sama, saling berkomunikasi dan saling membantu dalam memahami suatu permasalahan. Desain penelitian ini menggunakan 2 Siklus, dilaksanakan di SMAN 2 Narmada Lombok Barat pada semester ganjil tahun pelajaran 2017-2018. Subyek penelitian adalah siswa kelas XII IPA-2 yang berjumlah 24 orang. Pengumpulan data dilakukan dengan observasi untuk memperoleh data aktivitas siswa dan tes untuk memperoleh hasil belajar siswa. Analisis data dilakukan dengan membadingkan rata-rata data pada siklus 1 dengan data pada siklus 2. Berdasarkan hasil penelitian pembelajaran tipe NHT ini dapat meningkat aktifitas belajar siswa, persentase keaktifan siswa meningkat dari $75 \%$ pada siklus I menjadi $79,17 \%$ pada siklus II. Demikian juga hasil belajar siswa mengalami peningkatan dari rata-rata kelas 78,60 pada siklus I menjadi 88,60 pada siklus II. Ketuntasan klasikal juga meningkat dari $80 \%$ pada siklus I menjadi $92 \%$ pada siklus II. Sedangkan respon siswa terhadap pembelajaran tipe NHT ini hampir semua menyatakan sangat setuju karena dianggap mudah dipahami, menyenangkan dan dapat digunakan untuk pembelajaran selanjutnya.
\end{abstract}

Kata kunci: Kooperatif; Numbered Heads Together; Hasil Belajar; Matriks.

\section{Pendahuluan}

Penguasaan terhadap ilmu pengetahuan khususnya matematika merupakan titik tolak untuk mengejar dan menguasai teknologi, karena matematika bukan hanya dibutuhkan sebagai alat berhitung pasif, tetapi merupakan bahasa inti bagi perumusan semua teori yang melandasi semua bidang studi (Nasution, 1982:4). Salah satu aspek yang menjadi konsentrasi adalah penyempurnaan di bidang pembelajaran (Sugiarti, 2004:41). Pembelajaran merupakan hal yang sangat penting untuk diadakannya penyempurnaan karena pendidikan yang pernah dilaksanakan masih didominasi oleh pengetahuan sebagai suatu perangkat fakta yang harus dihafal dan hanya berfokus pada paradigma guru sebagai satusatunya sumber utama dalam pengetahuan dan ketrampilan dalam pembelajaran. Salah satu aspek dalam pembelajaran adalah interaksi antar siswa yang direncanakan harus sesuai dengan tujuan pembelajaran. Pada metode pengajaran ceramah oleh guru, sebagian besar siswa tidak mampu menghubungkan sesuatu yang telah dipelajari dengan pemanfaatannya dalam kehidupan mereka, sehingga dapat mengakibatkan kurangnya hasil belajar siswa dan lemahnya 
motivasi belajar siswa serta hanya belajar dengan menghafal (Sugiarti, 2004:43). Hal tersebut menunjukkan bahwa dalam pembelajaran perlu penyempurnaan dan perbaikan pembelajaran baik dari segi metode pembelajaran maupun dari cara siswa belajar.

Pembelajaran yang sesuai pandangan baru adalah pembelajaran yang diarahkan pada kegiatan-kegiatan yang mendorong siswa untuk belajar secara aktif baik fisik, mental, dan sosial untuk memahami konsepkonsep matematika. Dengan demikian proses pembelajaran lebih difokuskan kepada siswa aktif dan kreatif sehingga proses belajar mengajar siswa akan mencapai pemahaman yang efektif dan efisien.

Dalam perbaikan dan penyempurnaan pembelajaran saat ini telah dikembangkan pembelajaran kooperatif (Cooperatif Learning), diantaranya adalah model Numbered Heads Together (NHT). Model pembelajaran ini merupakan salah satu model pembelajaran dengan mengelompokkan beberapa siswa dalam satu kelompok sehingga anggota dalam tiap kelompok dapat saling berdiskusi untuk menyelesaikan setiap permasalahan yang diberikan guru (Isjoni, 2011:68).

Mempelajari matematika membutuhkan ketekunan dan kreativitas yang tinggi. Para individu yang smart memahami bahwa dengan belajar matematika secara enjoy akan dapat meningkatkan daya nalar. Hal ini yang kadang tidak disadari sebagian siswa, mereka menganggap bahwa pelajaran matematika sulit dan membosankan. Dengan anggapan yang salah itu maka berdampak pada keberhasilan mereka dalam pembelajaran.

Dari hasil perolehan nilai ulangan harian di kelas XII IPA-2 menunjukkan rata-ratanya terus merosot yaitu 54,52 sementara Kriteria Ketuntasan Minimal (KKM) yang ditetapkan sekolah untuk mata pelajaran matematika adalah 75. Ini jelas mengindikasikan bahwa matematika masih menjadi momok bagi sebagian besar para siswa khusunya kelas XII IPA-2. Untuk mengatasi permasalahan inilah guru dituntut untuk dapat mengembangkan strategi, metode maupun pendekatan yang cocok untuk memperoleh hasil yang diinginkan.

Konsep Matriks adalah salah satu bagian dari matematika yang sangat memerlukan ketelitian, kecermatan dan daya nalar dalam menyelesaikan setiap permasalahannya, dibutuhkan ketekunan dan kesabaran dalam mempelajari konsep ini. Konsep Matriks adalah salah satu bahasan dalam Matematika yang belum diajarkan pada jenjang pendidikan sebelumnya (di SD dan SMP), untuk itu diperlukan strategi khusus dalam menyampaikan materi ini. Pada kesempatan ini penulis mencoba mengaplikasikan satu metode pembelajaran yang membantu siswa meningkatkan aktivitas dan perolehan hasil belajar dalam mempelajari konsep Matriks dengan menerapkan pembelajaran kooperatif Numbered Heads Together (NHT).

\section{Metode}

Penelitian ini adalah Penelitian Tindakan Kelas (PTK). Penelitian tindakan kelas adalah salah satu srategi pemecahan masalah yang memanfaatkan tindakan nyata dan proses pengembangan kemampuan dalam mendeteksi dan memecahkan masalah pembelajaran dalam kelas (Arikunto, 2006). Dalam dunia pendidikan kelas merupakan unit terkecil dalam sistem pembelajaran, sehingga semua guru perlu mendalami dan berperilaku kritis terhadap apa yang sebenarnya dilakukan oleh siswa maupun guru dan apa sebenarnya yang terjadi sehingga guru akan dapat menentukan sendiri bagaimana strategi mengubah dan meningkatkan efektivitas dan efisiensi pembelajaran di kelasnya secara kontekstual.

Adapun langkah penelitiannya bersifat refleksi tindakan dengan pola proses pengkajian berdaur siklus. Langkah ini berlangsung berulang-ulang yang meliputi tahapan Perencanaan - Tindakan - Observasi - Refleksi. Pelaksanaan tidakan minimal dua 
siklus dan tahapan penelitian menggunakan model Kemmis - Taggart.

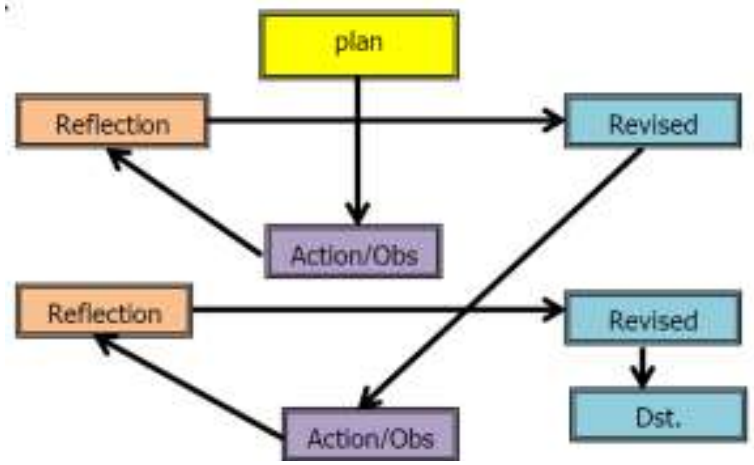

Gambar 1. Siklus PTK model Kemmis-Taggart (Depdiknas : 1999)

Obyek penelitian adalah siswa kelas XII IPA-2 tahun pelajaran 2017 - 2018 SMA Negeri 2 Narmada Kabupaten Lombok Barat dengan jumlah siswa 24 orang, yang terdiri dari 8 siswa laki-laki dan 16 siswa perempuan, adapun alasan pemilihan kelas XII IPA-2 adalah karena sebagian besar siswa di kelas ini mempunyai kecenderungan ramai dan aktif namun kurang terarah.

Subyek penelitian ini adalah guru pengajar matematika kelas XII IPA-2, yang dalam hal ini adalah penulis sendiri dan melibatkan rekan guru matematika lain sebagai kolaborator. Pengumpulan data dalam penelitian ini bertujuan untuk mendapatkan bahan-bahan yang relevan, akurat dan sesuai dengan tujuan penelitan. Metode yang digunakan untuk mengumpulkan data dalam penelitian ini adalah observasi, interview atau wawancara dan tes.

Analisa data merupakan cara yang paling menentukan untuk menyusun dan mengolah data yang terkumpul sehingga dapat menghasilkan suatu kesimpulan yang dapat dipertanggungjawabkan. Analisa data pada penelitian ini adalah deskriptif kualitatif terhadap data yang didapat dari hasil observasi dan wawancara, sedangkan analisa data kuantitatif berwujud angka-angka dari data yang diperoleh dari tes dan observasi. Data yang akan dianalisa pada penelitian ini adalah : 1) aktivitas siswa, 2) aktivitas guru, 3) efektivitas siswa, 4) tes awal dan tes akhir.

\section{Hasil dan Pembahasan}

Pada pembelajaran kooperatif model Numbered Heads Together (NHT) ini sebelumnya siswa dibagi dalam 6 kelompok yang diberi nama A, B , C , D dan seterusnya sampai $\mathrm{F}$, dimana tiap-tiap kelompok terdiri dari 4 siswa dan masing-masing siswa diberi nomor A-1 , A-2 , A-3 , A-4 ; B-1, B-2 , B-3, B-4 dan seterusnya sampai F-1 , F-2 , F-3 , F-4. Pembagian kelompok didasarkan dari data jumlah nilai ulangan harian mata pelajaran yang menjadi karakteristik jurusannya (Matematika, Fisika, Kimia dan Biologi) pada semester gasal 2017-2018, hal ini dilakukan karena penelitian dilaksanakan pada akhir semester ganjil.

\section{Siklus I}

Pada tahap perencanaan peneliti menyiapkan semua bahan yang akan digunakan dalam pembelajaran model NHT ini diantaranya: Rencana Persiapan Pembelajaran (RPP) untuk pertemuan I dan II, Lembar Kerja Siswa (LKS) untuk pertemuan I dan II, instrumen observasi dan tes akhir siklus (tes formatif I).

Pembelajaran pada siklus I dilaksanakan pada minggu pertama bulan September sebanyak 3 kali pertemuan. Pada pertemuan I materi yang dibahas adalah pengertian, sifat, ordo dan kesamaan Matriks. Siswa mengelompok menurut kelompoknya masingmasing dan membentuk posisi lingkaranlingkaran kecil. Masing-masing siswa memakai nomor yang sesuai dengan nomor kelompoknya dan dipakai di kepala. Pada pertemuan ini tiap kelompok membahas Lembar Kerja Siswa (LKS) I dan tiap kelompok diberi waktu 30 menit untuk berpikir bersama dalam memahami isi LKS dan menyelesaikan soal-soal yang ada. Setelah proses pemahaman 
selesai, maka guru memanggil salah satu nomor dan yang nomornya disebut mengacungkan tangan dan maju ke papan tulis untuk mempresentasikan hasil jawabannya pada seluruh kelas. Begitu seterusnya sampai soal-soal yang ada dalam LKS I terselesaikan dan seluruh siswa memahami permasalahan dalam LKS I tersebut. Pada akhir pertemuan siswa diberi tugas mengerjakan soal-soal tugas individu sebagai pekerjaan rumah.

Selama pelaksanaan (action) dilakukan observasi terhadap aktifitas belajar oleh observer (teman sejawat) yang bertindak sebagai kolaborator. Adapun aspek yang diamati untuk mengetahui aktivitas belajar siswa meliputi: 1). Memperhatikan penjelasan guru, terdapat 3 indikator, 2). Berdiskusi/bertanya antar siswa dalam kelompok, terdapat 3 indikator, 3). Bertanya kepada guru, terdapat 3 indikator, 4). Pemahaman materi dengan mengerjakan LKS, terdapat 3 indikator, 3). Presentasi pertanyaan (memperhatikan atau memberikan tanggapan dalam kegiatan presentasi), terdapat 3 indikator.

Dari hasil observasi pelaksanaan tindakan siklus I diperoleh data 18 siswa yang aktif dan 6 siswa cukup aktif. Atau dapat dikatakan dari 24 siswa, yang aktif mengikuti pembelajaran adalah $75 \%$. Dari hasil tes formatif I diperoleh data bahwa dari 25 siswa terdapat 5 siswa yang mendapat nilai dibawah 75 dan 20 siswa mendapat nilai 75 keatas. Berdasarkan kriteria ketuntasan minimal (KKM) untuk materi Matriks adalah 75, maka ketuntasan belajar klasikal adalah $80 \%$ dan rata-rata kelasnya 78,60 .
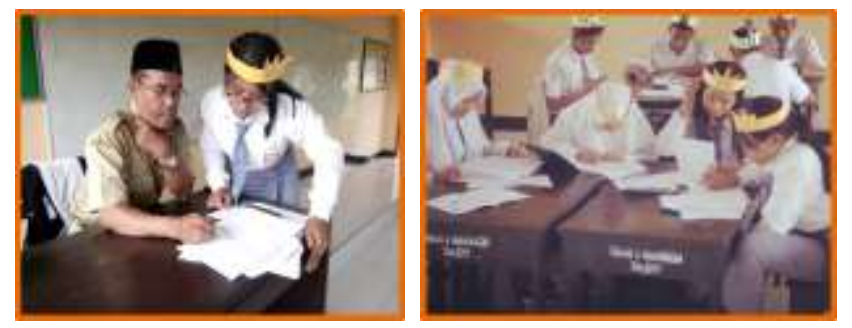

Gambar 2: Aktivitas Pembelajaran pada Siklus I

\section{Siklus II}

Pada tahap ini peneliti menyiapkan Rencana Persiapan Pengajaran (RPP) III dan IV untuk dua pertemuan berikutnya, Lembar Kerja Siswa (LKS) III dan IV, tes formatif II, lembar observasi dan pembagian kelompok yang telah mengalami perubahan. Daftar pembagian kelompok untuk siklus II terlampir.

Siklus II dilaksanakan pada minggu ketiga bulan September sebanyak 3 kali pertemuan. Dua kali pertemuan dialokasikan untuk kegiatan pembelajaran dan satu kali pertemuan digunakan untuk tes formatif II. Mengacu dari hasil refleksi pada siklus I maka pada tahap pelaksanaan siklus II ini lebih ditekankan pada aspek pemahaman siswa dan kerja sama tiap-tiap kelompok. Dalam setiap kelompok diupayakan untuk lebih meningkatkan komunikasi dalam usaha untuk memahami materi maupun latihan-latihan soal yang ada dalam LKS III dan LKS IV. Guru berkeliling untuk memberi bantuan kepada kelompok yang merasa belum memahami konsep. Dalam pelaksanaan siklus II ini juga dilakukan observasi terhadap aktifitas siswa dalam pembelajaran, baik dalam pertemuan IV maupun pertemuan $\mathrm{V}$.

Hasil Obsevasi pada pelaksanaan (action) pembelajaran siklus II ini diperoleh data tentang aktifitas siswa yaitu 19 siswa aktif dan 4 siswa cukup aktif, atau dengan kata lain dari keseluruhan siswa $79,17 \%$ yang aktif mengikuti pembelajaran dan yang lainnya cukup aktif. Dari hasil tes formatif II diperoleh data 2 siswa memperoleh nilai kurang dari 75 dan 23 siswa memperoleh nilai 75 keatas, sehingga dapat disimpulkan ketuntasan klasikalnya adalah $92 \%$ dan rata-rata kelasnya 88,60 .

Perubahan yang terjadi dari siklus I ke siklus II baik dari segi hasil belajar maupun aktifitas siswa. Dari hasil belajar siswa mengalami peningkatan dari rata-rata kelas 78,60 menjadi 88,60, dan dari ketuntasan klasikal dari $80 \%$ menjadi 92\%, sedangkan 
dari jumlah siswa yang tidak tuntas dari 5 orang menurun menjadi 2 orang.

Pada siklus I prosentase siswa aktif $(\mathrm{Pa})$ adalah $75 \%$ sehingga masuk dalam kriteria aktif, sedangkan pada siklus II prosentase siswa aktif $(\mathrm{Pa})$ adalah 79,17 \% sehingga masuk dalam kriteria sangat aktif. Ini menunjukkan bahwa penggunaan metode Numbered Heads Together pada pembelajaran materi Matriks ini dapat meningkatkan hasil belajar maupun aktifitas siswa. Selain itu juga pada pembelajaran ini juga dapat meningkatkan kerja sama antar siswa dalam membagi informasi khususnya dalam pemahamam materi pelajaran sehingga semua materi dapat terserap oleh siswa tidak hanya melalui guru tapi juga melalui interaksi antar sesama siswa.

Respon siswa terhadap pembelajaran ini juga sangat baik, dari angket siswa yang peneliti bagikan terhadap semua siswa hampir $75 \%$ sangat setuju bahwa pembelajaran menggunakan metode Numbered Heads Together (NHT) ini dapat digunakan sebagai salah satu metode dalam pembelajaran.

Tabel 1. Data Hasil Angket Siswa tentang Penggunaan Metode NHT Sebagai Model Pembelajaran Matematika

\begin{tabular}{llllllll}
\hline \multirow{2}{*}{ No } & \multirow{2}{*}{ Pernyataan } & \multicolumn{9}{c}{ Frekuensi } & \multirow{2}{*}{ Jumlah } \\
\cline { 3 - 7 } & MS & S & TT & TS & STS & \\
\hline 1 & Menyenangkan & 22 & 1 & 1 & - & - & 24 \\
2 & Menarik & 14 & 9 & 1 & - & - & 24 \\
3 & Mudah & 18 & 4 & 1 & 1 & - & 24 \\
4 & Lebih Baik & 14 & 9 & 1 & - & - & 24 \\
5 & Metode dapat dilanjutkan & 21 & 3 & - & - & - & 24 \\
& Jumlah & & & & & & 120 \\
& Prosentase & 74,17 & 21,67 & 3,33 & 0,83 & 0 & \\
\hline
\end{tabular}

Dari tabel di atas juga terlihat ada satu siswa yang hampir menjawab tidak tahu dari semua indikator yang ada, hal ini disebabkan siswa yang menjawab tidak tahu tersebut adalah siswa yang tidak pernah ikut dalam setiap pertemuan karena ada tugas mewakili sekolah, dan satu siswa yang menjawab tidak setuju jika pembelajaran ini dianggap mudah adalah siswa yang kurang bisa berkomunikasi dengan teman sesamanya karena merasa malu dan minder dengan kekurang mampuannya.
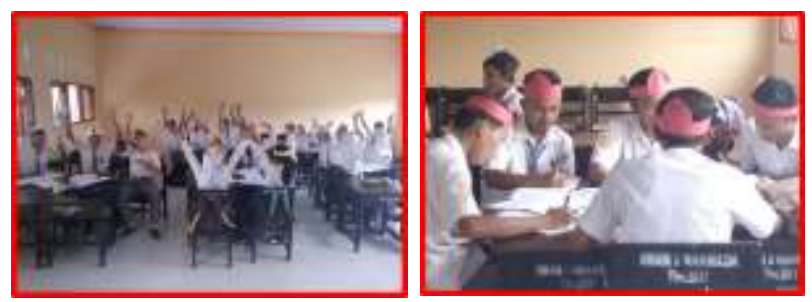

Gambar 3: Aktivitas Pembelajaran pada Siklus II

Selain itu juga dari hasil wawancara yang dilakukan kolaborator terhadap siswa juga diperoleh kesimpulan bahwa hampir semua siswa memberi tanggapan yang positip terhadap semua pertanyaan yang ada dalam pedoman wawancara untuk siswa.

\section{Kesimpulan}

Sesuai dengan rumusan masalah dan tujuan penelitian maka secara umum dapat disimpulkan bahwa aktivitas siswa untuk mengkonstruksi pengetahuan mereka sendiri cenderung meningkat baik dalam hal mengerjakan LKS, berdiskusi, bertanya antar teman dan merespon pertanyaan teman. Hasil belajar siswa pada materi Matriks mengalami peningkatan setelah dilaksanakan pembelajaran model NHT. Ketrampilan kooperatif siswa meningkat selama KBM karena setiap siswa dalam kelompoknya saling bekerja sama dalam memahami materi Matriks. 


\section{Daftar Pustaka}

Arikunto S. (2006). Prosedur Penelitian Suatu Pendekatan Praktik. Rineka Cipta: Jakarta

Isjoni. (2011). Pembelajaran Kooperatif. Pustaka Pelajar: Yogyakarta

Nasution, S. (1982). Didaktik Azas-azas Mengajar. Jemmars: Bandung

Pusat Pengembangan Kurikulum. (2004). Kurikulum 2004 SMA Pedoman Khusus Pelajaran Matematika. Depdiknas: Jakarta

Sugiarti, T. (2004). Metode Penelitian Pendidikan. Alfabeta: Bandung

Tim Pelatihan Proyek PGSM. (1999). Penelitian Tindakan Kelas. Depdikbud, Jakarta Http://www.epsilon.com 